\title{
24
}

PROJECT MUSE

\section{Madrid Río, El Matadero and the Nature of Urbanization}

Matthew I. Feinberg, Susan Larson

Arizona Journal of Hispanic Cultural Studies, Volume 23, 2019, pp. 175-190

(Article)

Published by University of Arizona

DOI: https://doi.org/10.1353/hcs.2019.0000

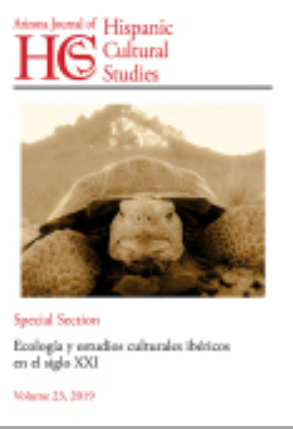

$\Rightarrow$ For additional information about this article https://muse.jhu.edu/article/756736 


\title{
Madrid Río, El Matadero and the Nature of Urbanization
}

\author{
Matthew I. Feinberg \\ Department of World Languages, \\ Literatures, and Cultures \\ Baldwin Wallace University \\ 275 Eastland Rd. \\ Berea, OH 44017 \\ feinberg@bw.edu
}

\author{
Susan Larson \\ Department of Classical and Modern Languages \\ and Literatures \\ Texas Tech University \\ 2906 18th Street \\ Lubbock, TX 79409 \\ susan.larson@ttu.edu
}

Resumen: Este ensayo considera dos proyectos urbanos que juntos han renovado el paisaje de la región sureña de Madrid desde 2007: Madrid Río y El Matadero Madrid Centro de Creación Contemporánea. Mientras que el primer proyecto se asocia con cambiar la ecología 'natural' de la ciudad y el segundo del paisaje cultural, ambos Madrid Río y El Matadero mercantilizan los conceptos de la sostenibilidad ecológica y la naturaleza. Analizamos la circulación de estos discursos de lo natural y lo ecológico y cómo se relacionan y se expresan a nivel material en el paisaje urbano. De ahí, apuntamos que estos proyectos encuentran nuevas maneras de encerrar, contener, cercar y vender la "Naturaleza" en Madrid a escala global. Como resultado, Madrid Río y El Matadero demuestran cómo la producción cultural estructura la relación y entendimiento de la sensibilidad ecológica. La producción de nuevos ambientes urbanos y la infraestructura que los hacen posible (las condiciones metabólicas y tecnologías que permiten el flujo de energía, comida, información, cuerpos y cosas) están siempre mediados por arreglos institucionales que a veces son democráticos pero a la vez son siempre involucrados en la expansión de la circulación del capital, y por ende un proyecto implícitamente antiecológico.

Palabras clave: ecología urbana, Madrid, gentrificación, Madrid Río, El Matadero Madrid Centro de Creación Contemporánea

\begin{abstract}
This essay considers two closely related high-profile urban renewal projects that have altered the landscape of the southern region of Madrid since 2007: Madrid Río and El Matadero Madrid Centro de Creación Contemporánea. While the former is often cast as renovating the 'natural' ecology of the city and the latter a renovation of its cultural landscape, both Madrid Río and El Matadero commodify the closely related concepts of ecological sustainability and nature. By analyzing the circulation of these discourses of nature and ecological sustainability along with their material expression in the urban landscape, we argue that these projects find new ways of enclosing, containing, packaging and selling Nature in Madrid on a global scale. In doing so, the Madrid Río and Matadero throw into relief the ways that cultural production frames our relationship and understanding of ecological sensibility. The production of new urban environments and the infrastructure that makes them possible (the metabolic conditions and technologies that permit for the flow of energy, food, information, bodies, and things) are always mediated by institutional arrangements that are occasionally democratic, but are always deeply committed to the unending expansion of the circulation of capital — a prospect that is implicitly not ecological.
\end{abstract}

Keywords: urban ecology, Madrid, gentrification, Madrid Río, El Matadero Madrid Centro de Creación Contemporánea 
Matthew I. Feinberg is an assistant professor of Spanish in the Department of World Languages, Literatures, and Cultures at Baldwin Wallace University. His research examines the physical and imaginary contours of contemporary Spanish culture through the study of dramatic texts, performance spaces, urban planning documents, and the transformation of urban space in twenty-first century Madrid.

Susan Larson is the Charles B. Qualia Professor of Romance Languages at Texas Tech University and Executive Editor of the Romance Quarterly. Her research lies at the intersection of Cultural and Urban Studies and explores competing discourses of modernity in Spain since 1900.
$\mathrm{M}$ adrid is part of a world-wide network of what Saskia Sassen calls 'global cities' in that it is a serious contender in contemporary inter-city competition for investment and tourism. At the same time, however, a significant number of influential economic and political theorists from several disciplines as early as 2007 have looked to Madrid's particular infrastructure and urban politics as a kind of 'canary-in-the-coalmine' test case scenario for their home countries because they, too, were looking down the barrel at the possibility of devastated housing markets, bank bailouts, and austerity measures (López and Rodríguez 2011; Swyngedouw 2011; Harvey 2012; Castells 2012; Brenner 2013). Portugal, Italy, Greece and Spain: these four Southern European countries or 'P-I-G-S,' with their bids for economic aid, were cautionary tales for the rest of the Eurozone and the world. The $15 \mathrm{M}$ movement (a precursor to New York City's Occupy Wall Street) that erupted in Madrid's Puerta del Sol in May of 2011 and later in plazas across Spain would open the door to a new urban politics emphasizing horizontality, participation, and a celebration of the commons. Since then, 15M expanded into a broader, longterm march toward political radicalization that resulted in the kinds of serious discussions of municipalism that have not taken place in Europe since the Eurocommunism movement of the late 1960s and early 1970s. In the last ten years in particular, Madrid has witnessed radical changes in demographic trends, the failure of the neoliberal state to control the economic crisis, changes in the global division of labor, cracks in globalization's myth of the mobility of people and goods, the increasing social and economic segregation of the city through gentrification, and last but certainly not least, impending ecological threats that force the city's inhabitants to alter their current understanding of what a city is and can be.

This essay looks at the discourses of nature and ecology of Madrid Río and El Matadero Madrid Centro de Creación Contemporánea, two closely related projects that are showpieces of Madrid's urban reform in recent years. As we have argued earlier (Feinberg and Larson "Cultivating the Square") drawing on the work of geographer Erik Swyngedouw, "Nature as a concept has become a rhetorical and ideological tool to promote a neoliberal spatial reorganization of the globe" (116) As indicated in the introduction to this volume, this framing of nature plays a key role in perpetuating the economic systems underlying the ecological crisis before us. Recent directions in urban studies question nature/urban binaries and have 
encouraged us to think of the city (in this case, Madrid) as an "ecosystem of cultural, political and material relationships" (Feinberg and Larson, The Ecological Imperative 2016) and we argue that 'natural' or 'ecological' concepts of the city should rely not only on biological relationships that produce less pollution, less waste, and have more nature (i.e., green space), but should also be founded on a cultural experience of place that allows for more just and maybe, humane intersocial connections as well as between people and and their non-human cohabitants. How and where people have interactions with artistic production in the city reveals much about the material conditions in which people live.

Ecological degradation has become increasingly visible on a planetary scale in recent decades. Bruno Latour writes that without the idea that we have entered into a 'New Climatic Regime' we cannot understand the explosion of social and economic inequality, the scope of deregulation and privatization, and the rise of populism (15). Subsequently, there is a new appreciation within historical-geographical material thought for the importance of the social and material production of urban nature. Erik Swyngedouw makes clear in his 2018 essay "The Urbanization of Capital and the Production of Capitalist Natures" that the key concern of urban political ecology should be

not what kind of urban natures are present in the city, but rather about the capitalist form of urbanization of natures: the process through which all manner of non-human 'stuff' is socially mobilized, discursively scripted, imagined, economically enrolled (enclosed, privatized, and commodified) and physically metabolized/transformed to produce socio-ecological assemblages that support the urbanization process. (14)
As we will examine in the examples of Madrid Río and El Matadero, the production of new urban environments and the infrastructure that makes them possible (the metabolic conditions and technologies that permit for the flow of energy, food, information, bodies and things) that secure their functioning are always mediated by institutional arrangements that are occasionally democratic but are always deeply committed to the unending expansion of the circulation of capital.

\section{Madrid Río: An Ingenious Adaptation of Nature to Culture}

The urban has always taken shape through an ongoing relationship to nature, of course, in Madrid as elsewhere. As Daniel Frost explains in his Cultivating Madrid, his study of public space and middle-class culture in the Spanish capital during the nineteenth century,

the relations between natural and urban space are inescapably bound up in efforts to modernize the Spanish capital, which becomes an overdetermined symbol of national culture. (21)

Frost carefully analyzes novels, paintings, essays and urban treatises written in and about the Spanish capital between 1833 and 1890 , to better understand the dialectical relationships between nature and culture, order and artifice in Madrid's public landscapes. Public gardens in Madrid began to open in earnest after the death of Ferdinand VII in 1833, which ushered in a period of liberal parliamentary rule. It would not take long for Madrid's authors to write about what these new spaces 
meant to the city's inhabitants. Frost looks to Isidora, the protagonist of Benito Pérez Galdós's 1881 novel La desheredada, as one of the most insightful and articulate voices to define the central characteristics of public gardens such as the Retiro Park, which was open to the public after 1868. Isidora calls the park "un campo urbano, una ciudad de árboles y arbustos ... una ingeniosa adaptación de la Naturaleza a la Cultura" [an urban countryside, a city of trees and shrubs ... an ingenious adaptation of Nature to Culture] (quoted in Frost 25). Throughout the realist urban novel, nature is equated with the body of the protagonist Isidora, and both are packaged, contained and commodified in order to satisfy the appetites of Madrid's city dwellers.

Isidora's experience typifies the capital's green bourgeois playgrounds and spaces of leisure as 'campos urbanos' in the 1880s. Retiro Park, and other major green spaces in Madrid one hundred years later, have a somewhat different position within the flows of urban capital, however. As Benjamin Fraser argues in his 2007 essay "Madrid's Retiro Park as Publicly-Private Space and the Spatial Problems of Spatial Theory,"

\begin{abstract}
Madrid's Retiro Park [from the 1980s on] represents a turn away from nineteenth-century recreational uses of parks for respite and escape towards a twentieth- and twenty-first century model that values city space as important for capitalist accumulation. (687)
\end{abstract}

Fraser points out that renovations to the Retiro and its surrounding area in the 1980s and 1990s were part of Madrid's desire to restore its patrimony as much as they were to preserve a tourist-friendly sense of place. In order for tourism to succeed, class difference has to be erased from the urban landscape and minority groups removed, or more aggressively policed. Sharon Zukin argues that parks are key to how a city "uses culture as an economic base" (25), and the Retiro exemplifies this shift in the role of nature in the age of increasingly flexible and global urban capital accumulation with increased policing and control over who can and cannot occupy the park.

Similarly, in the mingling of aquatic flows and the flows of global capital circulating around the Madrid Río, the redevelopment of Madrid's Manzanares River into a linear park as it courses through the city also calls attention to the way urban planning 'discursively scripts [and imagines]' the natural world. There is a certain irony to this redevelopment project given that the Manzanares river has rarely been celebrated as one of Madrid's endearing features-especially to foreign eyes. There is, for example, the story from the late sixteenth century of an ambassador of the Holy Roman Emperor who sardonically celebrated the greatness of the river because it was both "navegable en coche y a caballo" [navigable by carriage and on horseback] ("El Manzanares" 902). In 1833, the travelogue of the Englishman Richard Ford goes even further and refers to the Manzanares as "'a miserable brook' ... which has the appearance of a river without a river's flowing water" (quoted in Ferrer 62). Since the river's canalization in various stages from the 1920s through the 1940s, as it passes through the capital, the river has often appeared more as urban canal than free-flowing river. Barely navigable as it streams through its channel of concrete and granite, the Río Manzanares is often overlooked as a feature of Madrid's physical geography. Over the last decade, since the construction of the 10-kilometer greenway park called Madrid Río that 


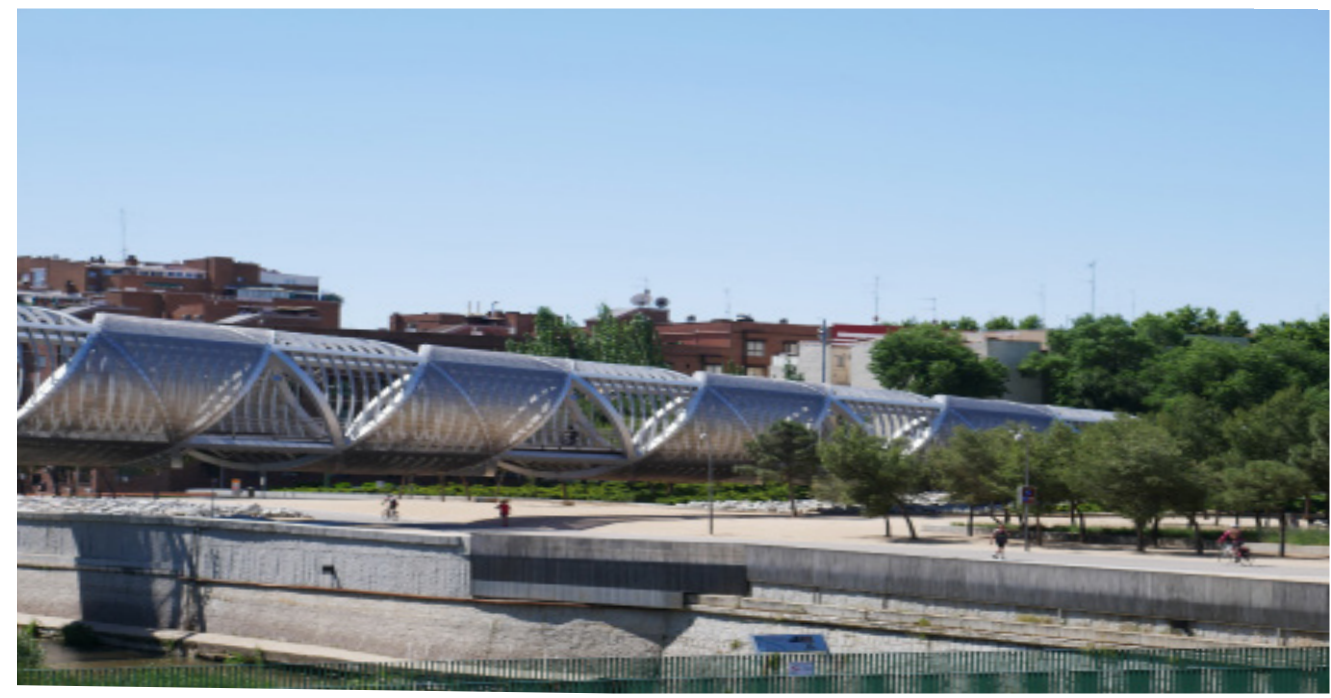

Fig. 1 La Pasarela Arganzuela by architect Dominique Perrault. Photo by Matthew I. Feinberg

opened in 2011, the river appears to have become more central to Madrid's image, and even finds its way into a 2016 Fodor's listicle of the ""16 Under-the-radar Things to Do in Madrid" (Kemper). Celebrating the river as an urban development project, the writer refers to the trails, to the green space, and even to the performance spaces that make up the park. Alongside the description, though, notably, is not an image of the river, but rather of the visually stunning Pasarela de Arganzuela designed by French starchitect Dominique Perrault (See Fig. 1). The spiraling metal form of the pedestrian bridge suggests that within the discursive currents of the Madrid Río, the river itself is merely an afterthought—particularly when the park is listed amongst a range of other cultural sites like the Museo del Prado, the Reina Sofía museum, the Palacio Real, and others, as is the case in the Fodor's article and other similar descriptions of tourist itineraries in Madrid.

Paradoxically, the Madrid Río park seems to elide the natural feature of the Manzanares River in favor of what could be understood as the cultural object called
Madrid Río. The presence of the three Puentes Cascaras, covered pedestrian bridges whose ceilings have mosaics made by the Spanish artist Daniel Conogar, reinforce this idea of the park as cultural object (see Figure 2). Likewise, we might look to the park's eastern end where we find the Centro de Creación Contemporánea Matadero Madrid, a dynamic and diverse cultural site with spaces dedicated to theater, cinema, art exhibitions, and even a small architectural and design library and makerspaces.

Despite the clear cultural array around which the park is built and organized, Ginés Garrido, the lead architect of the project from the firm Burgos and Garrido, entitles his 2017 overview for the Revista PH91 "Madrid Río, o el retorno de la urbe a la geografía del Manzanares" [Madrid Río or the City's Return to the Geography of Manzanares]. This focus on the geography of the river is echoed in key words or phrases that the author uses to tag the article like 'ecología,' 'zonas verdes,' 'medio ambiente,' and 'frente fluvial' [ecology, green zones, environment, riverfront] (Garrido 100).Contrasting or complementing this ecological discourse 
is what might be considered a more urban and/or sociocultural one that articulates the Madrid Río in terms of, in his words, 'espacio público' and 'patrimonio' [public space, patrimony] (Garrido 100). There is, in this array of key words, an allusion to the fundamental tension found in a project like the Madrid Río. It is a tension distilled in the duality of the park's name: Madrid and Río. Through linguistic juxtaposition, the name alludes to a union between the built environment of the city and its physical geography, "una intersección entre el tejido construido y el campo biológico del río" [an intersection between the river's constructed urban fabric and its biological field] (21), as Garrido describes it. Amidst this union is the key, perhaps, to the article's final key term, 'sostenibilidad social' [social sustainability] (100). The Madrid Río project is imagined (at least in the mind of its lead architect) as a means to create not only an ecology suitable for non-human living things, but also the ecology of the social environment. As David Harvey posits in his 1996 exploration of the intersections between environmentalism and geography, "the very design of the transformed ecosystem is redolent of its social relations" (Justice, 184), and thus deeply connected to what we have elsewhere called the 'cultural ecology of the city' (Feinberg and Larson "Cultivating the Square" 115)—a term that refers to the interdependent systems of cultural production that produce the socio-spatial environment. Our approach to the Madrid Río project takes, as a point of departure, Harvey's suggestion in Justice, Nature, and the Geography of Difference (1996) that we consider environmental debates "not for what they have to say about the environment or nature, but for what it is they say about political-economic organization" (176). It is

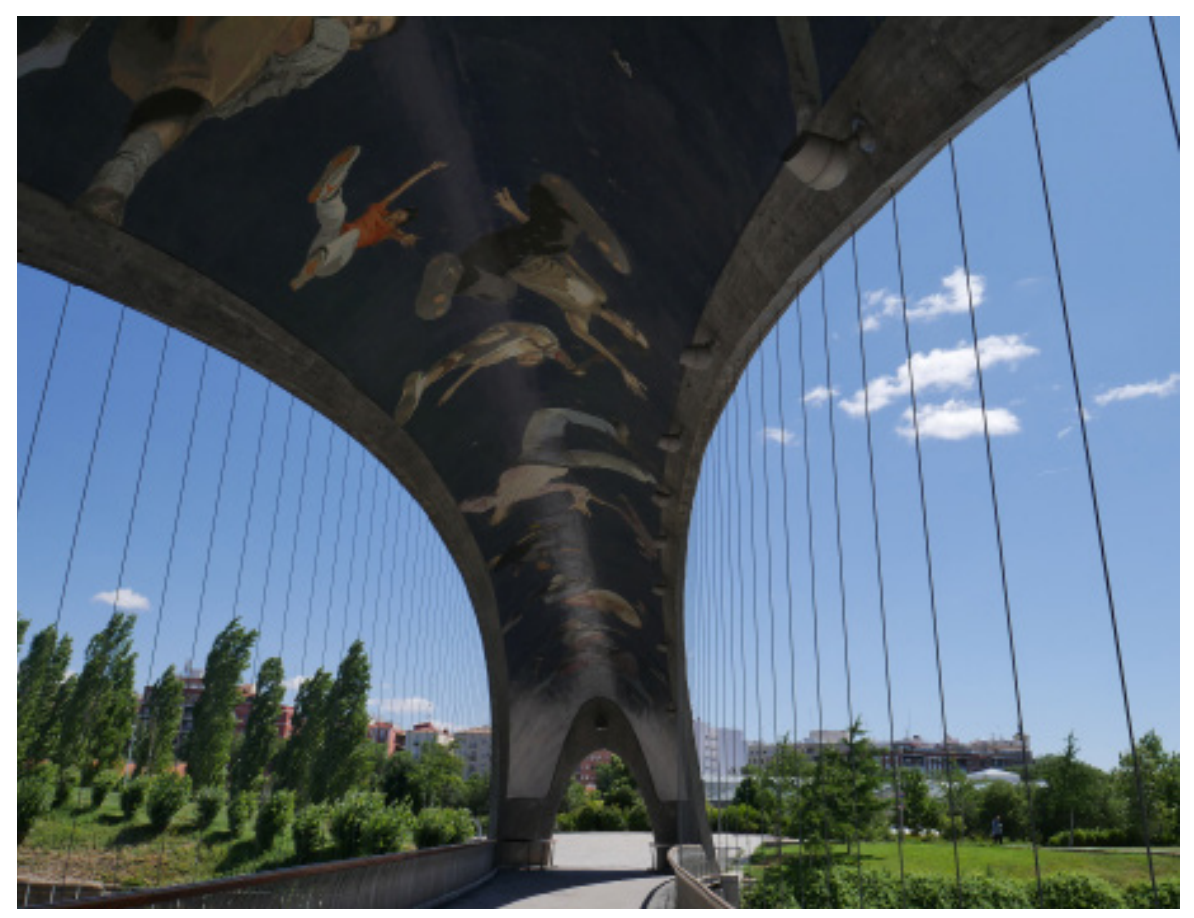

Fig. 2 Puente Cascara by Daniel Conogar. Photo by Matthew I. Feinberg 
safe to assume that Harvey would approve of taking this last point and changing the emphasis from political-economic organization to urbanism and urbanization in the twenty-first century. For these reasons, the union of Madrid and Río is an uneasy one, or, at the very least, a problematic one because, despite the frequent ecological discourses found in the writing of the designers, architects, and city planners about the project, it participates within a broader system of cultural production and urbanization. As the physical geography of the river is appropriated into a broader 'urbanization of consciousness' - to use another of Harvey's terms (1985) - it throws into relief the conflicts and conundrums that emerge from the intersection of discourses of the urban, the natural, and the cultural.

To consider the Madrid Río project only as cultural object is to forget that even the most urbanized rivers-the Gowanus Canal, the Cuyahoga River, the Nervión river in Bilbao-are still always natural-a linear aquatic thread connecting the various strands of the watershed. As the Manzanares travels its hardscaped path through the city it remains the same river as the one that emerges at its headwaters some 1,400 meters of elevation above the capital near the Navacerrada pass in the often-snowy peaks of the Sierra Guadarrama. Winding southwards out of the Central System mountains, the river changes form near the towns of Manzanares el Real and later near the royal villas of El Pardo to pause in large, human-constructed reservoirs before continuing on its journey towards the Jarama river some fifty-seven kilometers away. Before encountering the scattered housing developments and bedroom communities that now defend the perimeter of the metropolis, the river traverses the diverse landscapes of the ecotone formed in the interface of the various biomes: from the creeping juniper and Valsaín pines of the sierra to the holm oak, pine, willow, and ash trees of the dehesa found at the lower elevations (see Figure 3). It is hard to imagine these idyllic landscapes as the river enters the city near Valdemarín and passes by the interchange of the M-30 and M- 40 highways on the northwest edge of the city. Here, the river's trajectory becomes implicitly more urban, following the M-30 circular highway as it skirts the south-western edge of the city. The river's journey along this trajectory becomes a tour through the various periods of the city's cultural history: Juan de Herrera's Puente de Segovia from the sixteenth century; Pedro de Ribera's Baroque Puente de Toledo; the miraculous springs of the Ermita de San Isidro and its famous praderas [grassy meadows] immortalized by Francisco de Goya and the countless celebrations of Madrid's patron saint. Downstream, one encounters the vestige of more modern sites of pilgrimage like the now demolished Vicente Calderón Stadium, the former home to Atlético de Madrid, one of Madrid's most important football clubs (the most important for certain fans). Throughout much of this urban passage, the river seems subjugated to the functionalist urban plans from the 1940s of Pedro Bigador and his efforts to mitigate the river's periodic flooding.

Beginning near the Puente de Toledo, the river takes both a literal and more figurative turn as it begins to angle in an easterly direction. The terrain becomes more ambiguous: neither merely a natural feature of the physical geography of the meseta, nor the functionalist conduit for the effluvium of the city. It is here that it becomes or enters the Madrid Río park. Often likened to New York's Highline, this linear greenway differs in that, instead of repurposing an abandoned piece of urban infrastructure, the Madrid Río project is literally underpinned 


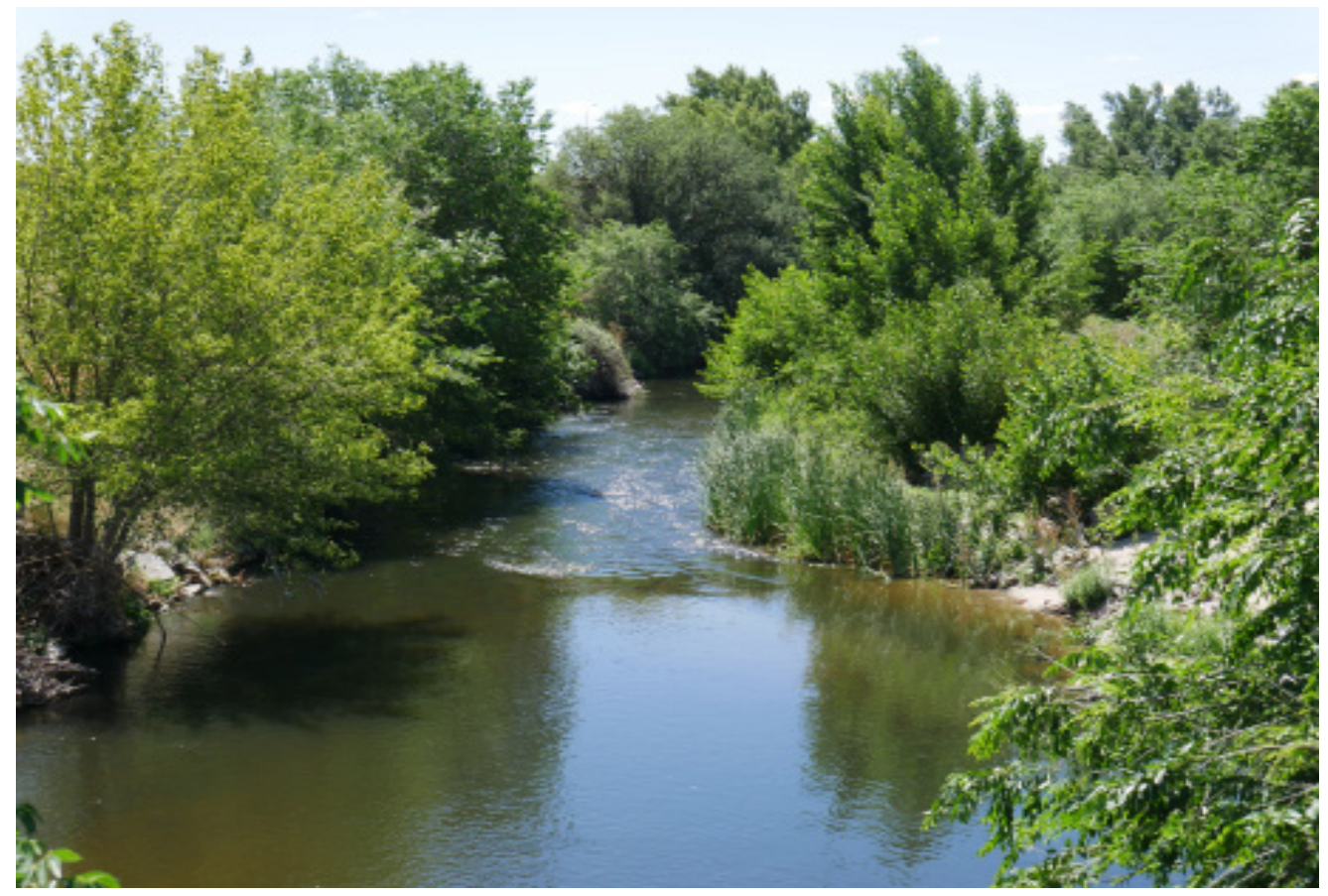

Fig. 3 Rio Manzanares on the outskirts of Madrid. Photo by Matthew I. Feinberg

by nearly nine and a half kilometers of the western branch of the M-30 highway and its junctions via a complex network of under ground roads at a cost of nearly 3.6 billion dollars. The park itself was the product of a 2005 design competition carried out by the municipal government. The winning entry in the competition came from a team of engineers, architects, landscape designers, biologists, and sociologists led by the aforementioned architectural offices of Burgos and Garrido, but also included others such as Porras La Casta, Rubio and Álvarez-Sala, and the Dutch design firm West 8. The park offers residents and visitors access to nearly 1,500 acres of open space as it follows the contours of the river and a connection to thirty kilometers of bike paths, eight different sports installations (including a skate park and basketball courts), fifteen playgrounds, spaces for performances, two cafés, and a restaurant. For many of the working-class residents on the south side of the river, whose median income hovers between 30,000 and 17,000 euros a year, these amenities are a welcome addition to neighborhoods that have historically been devoid of any legitimate public space, ignored because of their physical disconnection from the city center, and perpetually degraded by the roar of the M-30 highway (Garrido 106). Reinvigorating the newly available surface of the river has not only rearticulated the relationship between the city center and the river, but also reintegrated these historically isolated communities.

In addition to its more traditional park amenities, the Madrid Río park is unique because of the way that it celebrates the river's natural ecology, while also taking on its role as an object for cultural consumption. Indeed, in the co-authored article written 
for ARQ magazine, Francisco Burgos and Ginés Garrido suggest that "El proyecto se emprende como una sucesión de acontecimientos memorables del norte al sur de la ciudad" [the project unfolds as a succession of memorable events from the north to the south of the city] (20). These memorable events include, for example, the Salón de Pinos that the design firm West 8 describes as a choreography of 8,000 pine trees and which according to the architectural webzine Archeye contains

a repertoire of cuts, and a selection
of uniquely shaped trees, combined
with inclined planting [which] lends
a natural and sculptural character to
the space, creating a botanical monu-
ment. (Ortiz de Landazuri et. al)

Thus, nature functions less as - or withinan ecological system, but rather as a monument. Notably, it is not just sculptural in character, but has been crafted to symbolize the broader natural environment. The horticultural tribute includes 35,000 adult trees, 2,000 smaller trees, 400,000 bushes, that are combined with the already-existing flora present in Madrid's landscape. Likewise, the use of granite for a number of decorative and functional features throughout the park both evokes - according to the architects-both the stone found in the quarries of the center of the peninsula and the granite batholiths of La Pedriza that adorn the base of the Sierra Guadarrama. Yet this ornate display of nature not only evokes the ecosystem of the Río Manzanares and the highlands of the central meseta as it is organized into three distinct districts to reflect different regional forest-types found across Spain: the Atlantic and Mediterranean coasts as well as the ecosystems of the Manzanares fluvial system. The flora of the park reflects the various ecosystems of the
Iberian Peninsula and acts as a cabinet of curiosities for the capital. It is a taxonomic Kilometer Zero that gathers, organizes, and mediates the understanding of the rest of the peninsula, and lends the park a slight imperialist tinge. In the discursive imagining of Garrido and his architectural team, the Madrid Río project is suddenly not merely a park, but rather like an ecological version of Jorge Luis Borges's Aleph-containing all the ecosystems of the peninsula on the nineteenth step of the cellar. In an ecological frame, this horticultural abundance of the project is described as the new lungs of the city, and thus seen as a means of improving the environment, not only at the municipal and the regional scale, but also as a tool for mitigating the global crisis of climate change.

While these aspirations are noble, urban blogger José Fariña points out that by hiding the cars almost literally under the rug of the city, the project does not do much to deemphasize the role of automobiles in giving form to Madrid's metropolitan area. Fariñas critique also cogently points out that the park successfully connects the various neighborhoods through the construction or rehabilitation of twenty-one bridges, but that the failure to connect these neighborhoods in a linear way, along the length of the park through public transportation like light rail or buses, limits the connections across neighborhoods that are not adjacent. Likewise, other critiques of the bike paths online suggest that they appear to have been built by people that do not actually ride bikes for transportation, and, therefore, service cycling flaneurs casually consuming the park, rather than creating an actual alternative for communicating the city.

These critiques of the ecological value of the project and its associations with what might be called 'green growth' are put into a broader context when we 
consider other more subtle consequences that accompany this type of redevelopment. As an ecological spectacle of sorts, the Río Madrid project perpetuates a certain progressive image of the city that can be used in promotional materials for both real estate development and for tourists. For example, Garrido and Burgos celebrate the fact that the project has led to a doubling of housing values in the area (25). Likewise, we might note that a recent Business Insider article lists the adjacent neighborhood of Usera as one of the twenty-five most popular neighborhoods in the world whose AirBnB bookings have grown $228 \%$ percent in recent years (Tkaczyk). Despite the ecological discourses that are used to describe it by designers, architects, and city planners, when the Río Madrid is understood alongside the city's cultural attractions, it becomes yet another factor in what has been called the touristification of the city-that is, a gentrification caused by tourism.

\section{El Matadero: Democratic Cultural Ecology or Eco-Friendly Gentrification?}

While the Río Madrid uses the discourse of urban design to linguistically and materially make the natural landscape into a cultural object, El Matadero Madrid Centro de Creación Contemporánea-found at the eastern end of the Madrid Río park-also leverages ecological discourse as a means of cultural production. The Matadero is just the latest culture-based project to alter a Spanish city's landscape in recent years. From the 1992 Olympic Games that sold

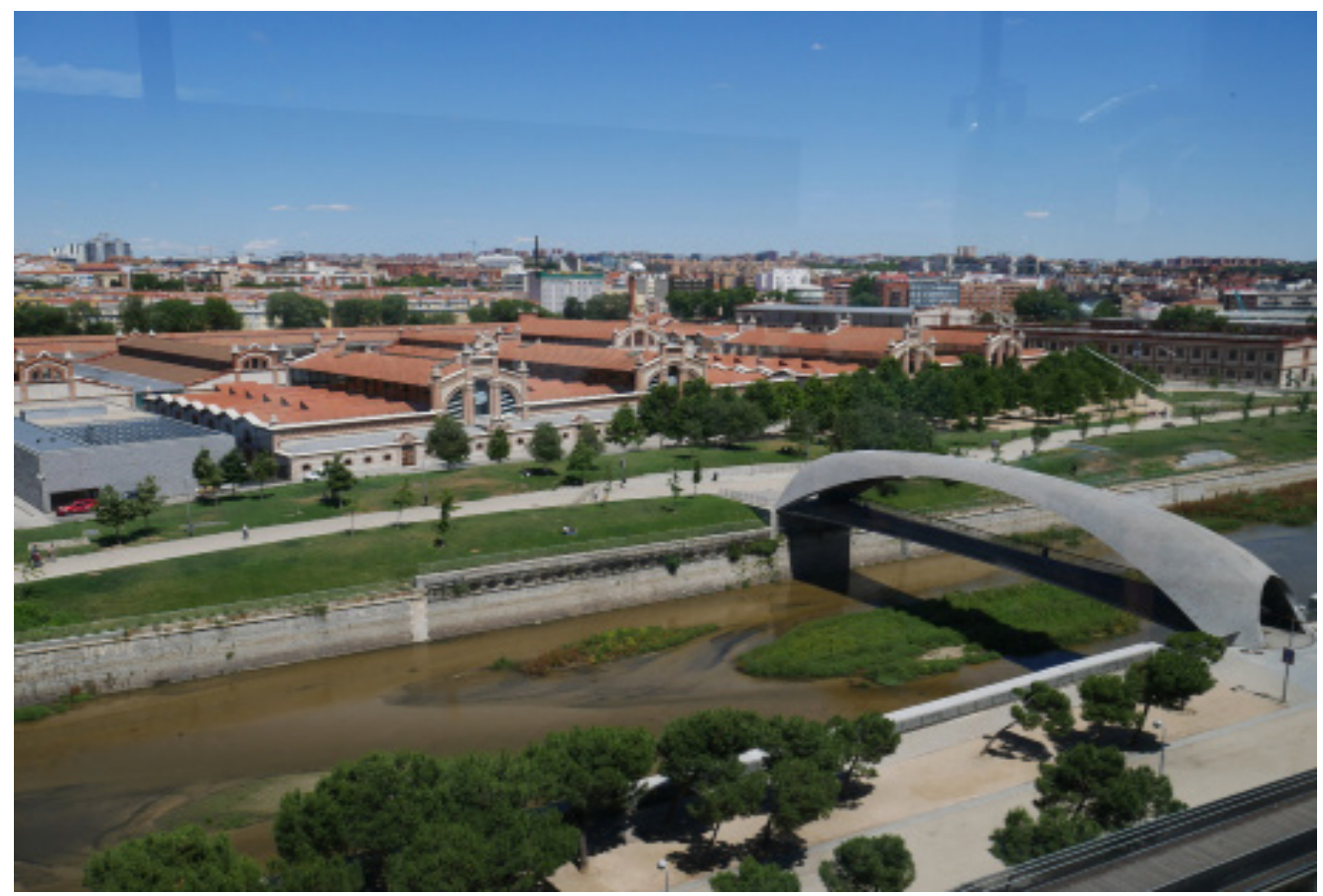

Fig. 4 View of the Matadero and one of the Puente Cascaras from Mirador Río 2. Photo by Matthew I. Feinberg 
the success story of Barcelona's regeneration process and Bilbao's 'Guggenheim effect' through to the 1990s, certain neighborhoods of Spain's cities have suffered the consequences of gentrification. In Barcelona, it is the Raval and Barrio Chino; while in Madrid, the names of neighborhoods like Malasaña, Chueca, Las Letras, Triball and Lavapiés have nearly become synonymous with gentrification, either as examples of a transformed neighborhood, or as sites where conflicts over housing, public space, and tourism continue to rage. Sequera and Janoschka argue in their case study of Triball and Lavapiés that gentrification in Madrid has its own particularities, such as the massive influx of more than 5 million migrants since 2000; the key role that high levels of public administration have historically played in Madrid; the tendency to favor the reconversion of working-class neighborhoods through commercial restructuration in Spain, and, lastly, how resistance to gentrification in Spain has been theoretically framed by a close collaboration between social movements and academics like those at the interdisciplinary research collective El Observatorio Metropolitano (Sequera and Janoschka 378-9)

The commonalities between the above-mentioned gentrification processes and the El Matadero project that accompanies the Madrid Río initiative are clear: all of them revalorize land close to the historic city center in ways that rearticulate their economic function and role in the symbolic imaginary. All of these initiatives structure investment policies around joint actions between public administrations and private concerns in order to bolster capital investment in commercial, cultural and real estate activities. If there is one difference in the strategies being used in the case of Madrid Río and El Matadero, however, it is a notable emphasis on the fetishization of nature in ways that draw attention to the changing relationship between the human and non-human through Madrid's history.

El Matadero has a lot in common with another, equally high-profile, ecofriendly park space and cultural center: New York City's Highline, the closelinked Hudson Yards Project, and 'the Shed,' which in 2013 received $\$ 50$ million from the City of New York to build what is, in essence, a performing-arts shell that glides along rails and seats 1,200 people. Despite their progressive artistic and ecological bonafides, the 'Shed' and the Highline cannot be extricated from the 20 billion dollar mega-plan located on the 12-acre site behind Penn Station and Madison Square Garden that will eventually hook the High Line with a new No. 7 subway station, made possible by new private / public investment strategies (and a project in which Michael Bloomberg invested $\$ 75$ million dollars of his own money). Madrid's equivalent of 'Shed,' simply called El Matadero ['The Slaughterhouse'], is a skillfully renovated space located in an area called la Dehesa de Arganzuela on the Manzanares River on the southern edge of the city and one of the anchors of the Madrid Río project. First constructed in 1911, it originally consisted of 48 pavilions that made up what was once an abattoir and livestock market and one of the most iconic industrial establishments in Madrid that was used until 1996 for these original purposes. After a brief stint in the 1990s, when the stalls for cattle were converted into the headquarters for Spain's National Ballet and National Dance Company, the complex, and the Madrid Río, began to be seen as anchor projects for the city 
leader's redevelopment of the city center's southern perimeter. In part due to the complex's extraordinary neo-mudéjar brickwork, Madrid's City Council decided to turn this space into an enormous arts center and cultural laboratory that began to take shape in earnest in 2007.

El Matadero preserves and celebrates its historic authenticity not only visually through its iconic architecture but also linguistically through names and references that allude to the meat production facility and the working-class communities that surrounded it for more than a century. The banks of the Manzanares have always been where Madrid placed its abattoirs, and the palimpsest of these working-class neighborhoods remains in the nomenclature of meat and blood that still defines the cartography for presentday tourists who flow down the sloping streets from the Plaza de Cascorro for the Sunday-morning open-air market known as 'El Rastro' [the Trail] located along the Ribera de Curtidores [meaning 'riverside of tanners'] and the adjacent streets and alleys between the Calle Embajadores and the Ronda de Toledo, just north of the historic slaughterhouses. The Rastro's enduring etymology forever connects the tanneries that were located in Ribera de Curtidores to El Matadero by the rastros [trails] of blood that the slaughtered cattle left in the streets of La Latina neighborhood down to the abattoirs located on the river.

In 2012, El Matadero, working with the City of Madrid, launched a clearer strategy called the Plan Estratégico de Cultura del Ayuntamiento de Madrid 2012-15 (PECAM) [Strategic Cultural Plan for City Government of Madrid 2012-15]. The city's stated goal in this plan was to recognize the importance of the cultural and creative industries and their potential contribution to economic recovery. The city [will] provide support for high quality cultural projects that promote employment, collaborate with other private and public sector bodies to develop municipal cultural activity, boost new models of financing and seek to establish Madrid as a first-rate international tourist destination. [...] Impacts can be analyzed according to two axes: urban regeneration and profile raising. Matadero Madrid activities have had an impact on urban regeneration in a non-central area. It is revitalizing, culturally and economically, the periphery of south Madrid, extending its cultural activity to other parts of the city. ("Matadero Madrid" np)

Those involved in making decisions about the space and its use were tasked with making El Matadero another cultural showcase to be used in the inter-city competition on which so much of our contemporary cities depend; a process that would result in turning the working-class neighborhoods surrounding El Matadero into yet more 'creative zones' or 'cultural hubs' that might spur private investment, redevelopment, and social transformation (i.e. gentrification). El Matadero, working with funding from the European Union's Culture for Cities and Regions program, articulates in this document the close connection between urban revitalization (planned gentrification), new modes of financing that facilitate private-public partnerships, and works under the premise that culture is an 'industry.' El Matadero occupies a 65,000 square meter area and is organized around 9 distinct projects, four of which are operated and controlled by Madrid's 
City Council and their cultural initiatives. These include the Intermediate, a space set aside for activities that bring in residents from the surrounding areas; the Naves de Español that house national and international theater productions; the Oficina de Coordinación that contains art galleries; space for artists in residence and archives, and the spectacular Cineteca Madrid, dedicated to the showing and discussion of documentary film. The other five structures making up the Matadero arts complex are privately run and include the Central de Diseño, the Extensión AVAM, the Casa del Lector, the building of the Germán Sánchez Ruiperez Foundation, and lastly, the Factoría Cultural, a kind of open workspace and incubator for up-and-coming creative collaborations.

El Matadero's adaptive reuse of industrial-scaled space is a far cry from Santiago Calatrava's extravagant, expensive, and grossly over-scaled City of Arts and Sciences in Valencia that serves as a decaying monument to Spain's economic boom years. This project on the Manzanares used a variety of extraordinary architects (many of whom were under- or unemployed after the economic crisis of 2007) to use every aspect of the already-existing structure and combine it with cheap industrial materials, such as exposed concrete, iron, steel mesh, and yards and yards of plastic butcher's curtains to create a visually fascinating and open series of spaces that constantly allude to the animals that previously inhabited the spaces. Perhaps one of the most stunning of the structures is the Casa del Lector [House of the Reader] designed by Anton García Abril that brings together three of the original meat storehouses and is made of brick, cast iron, and bright expanses of white that serve as a contrast to a bright red staircase that looks like what architectural critic Edwin Heathcoate says looks "like a gash of freshly slaughtered cow" ("Matadero Madrid, Spain" np).

Hand in hand with the visual and architectural references to animals that underline so many aspects of El Matadero is the constant attention to the importance of plant life and urban sustainability. Under the umbrella program named Intermedix, El Matadero has, according to their official website, created a series of spaces that
operates as a means for explora- tion research and experimentation. Process and participation are the formulas for its development. It works with the community; ecology, art and activism; games as a form of exploration; visual culture; archival processes and memory; and the Cre- ate Arts Grants program, as a way to collectively define the institution.
("Qué es Intermediæ")

The most notable, ecologically-focused space making up this project may be the carefully curated Avant-Garden, a project sponsored by the French-German group Atelier La Baltoin that consists of a long corridor along the Paseo de la Chopera. The primary flower chosen for the garden is the rose, but many other perennial plants have been introduced, and there are regularly-held workshops and meetings that are open to anyone interested in maintaining the space and learning about how to create a network of such reuse of green space with other communities in Madrid such as the Huerta de Roberto in Carabanchel, Esta es una Plaza in Lavapiés and the Huerta de Madrid Salud in Usera, with similar initiatives. Another point of ecological reflection and interest is the 'Depósito de especies,' which has been 
repurposed out of the water tank of the slaughterhouse that has been turned into a kind of plant memorial or archive; what El Matadero calls a 'Noah's Ark' of plant and insect species found around Legazpi today, and accessible close to the main entrance of the Legazpi roundabout.

Interactive connectors, modern cities bring people and ideas together and create new spaces for them to recombine in ways that make possible all sorts of artistic creativity, technological innovation and, of course, economic growth. As we attempt to show in this essay, Madrid Río and El Matadero are dynamic urban experiments that open up opportunities to better understand the changing relationship between the city, nature, and the future of the intersections between human and non-human life forms in the age of ecological crisis. Urban planning, architecture, and art are some of the most powerful ways that we as humans have to satisfy our need to engage with nature: our need for beauty; our need for emotional connection; and last but not least our need for collective engagement with the physical world. Any collective impetus looking for solutions to the ecological problems we face needs culture in the sense that it needs the inspiration of a poetic, imaginative love or appreciation of nature. Artistic expression and nature are also exceptionally good at giving us a chance to engage in critical dialogue with previous radical social movements that have developed rich cultures of resistance and visions of possible futures from which we can learn. This most recent use of Nature with a capital 'N' by public and private interests in Madrid, as a key component of its twenty-first-century capitalist accumulation strategy, tied to the use of the culture industry as municipal business initiative, however, runs the risk of depoliticizing, compartmentalizing and marketing the 'ecological' right out of existence for everyday urban citizens.
Indeed, the flows of the river and of the walkers, bikers, and skaters along the linear park echo a different kind of flow across the river from the Matadero. There, consumers, capital, and goods flow through the Plaza Río 2, a 40, 0000 square foot commercial center with more than 160 stores, restaurants, and kiosks. These include Starbucks, Häagen Dazs, Zara, Mango, and even a Five Guys Burgers. The top of the building is adorned with the Mirador Río 2, a vantage point that allows one to visually consume the Matadero complex, and the adjacent section of the Madrid Río park against the backdrop of the metropolis (See Figure 4).

The intertwined marketing of the Madrid Río project, with that of the mall, cannot be untangled from the Pryconsa realestate group's large residential construction project just down the road, upon which a large sign on the roof reads 'Aticos en venta' [Lofts for Sale]. That one of the company's main shareholders is the real-estate trust Saint Croix Holding Immobilizer alludes to the way that the Madrid Río-whether intentionally or not-has already begun to attract capital investment. Along with these real estate projects, the rental market continues to transform the area as AirBnB bookings increase by leaps and bounds in the neighborhoods surrounding the confluence of the Madrid Río and El Matadero. Both projects fetishize nature, but, unfortunately, have been quickly assimilated into Madrid's urban development strategy. Despite the best efforts to transform the urban cultural ecology of the metropolis, these projects-it seems-have merely continued the status quo, what Luis Prádanos has described as the "dominant imaginary of economic growth." (11). The problem, to quote geographer Erik Swyngedouw once more, is that "with an overly fetishized notion of Nature there can be no pursuit of solutions outside of a capitalist framework to resolve 
our growing ecological crisis" (276). Projects like Madrid Río and El Matadero reminds us that the challenge of climate change asks us to reconsider the ecological context of the built environment, not through the urbanization of nature- a process that converts Nature into a cultural object-but rather by cultivating cultural ecologies that imagine a post-growth urban environment.

\section{AFTERWARD: Renaturing the City?}

We finished this essay in June of 2019 against the backdrop of Madrid's latest battle over who will win and who will lose the 'right to the city' as a result of the renovation of the Plaza de España, an iconic space marking the end of the third and last section of the Gran Vía completed in the 1950s, ringed by modern skyscrapers and home to a monument to Cervantes himself. As of this writing, it is undoubtedly the city's most ambitious renovation project and the construction is surrounded by temporary safety barriers that define the new space as "una actuación que contribuye a la 'renaturalización de la ciudad' [an operation that contributes to the renaturing of the city]. Slogans for the project written on the safety barriers include 'De Madrid al campo' [From Madrid to the countryside], 'Una plaza más verde' [A greener plaza], 'Un proceso participativo' [A participatory process] and "Movilidad sostenible" [Sustainable mobility].

The project's stated mission presented on these barriers to the many thousands of people walking by every day is to bring the Casa del Campo to the Gran Vía by weaving together the Gran Vía, Calle Princesa, Parque del Oeste, Templo de Debod, Plaza de Oriente, Sabatini Gardens, Campo del Moro and, last but not least on the list, Madrid Río, which would bring this greening of the city full circle. The workers putting the finishing touches on the Edificio España (now the 26 story, 550-room Hotel RIU luxury hotel) that looms over the plaza, the appearance of minimalist, exquisitely designed collaborative "work spaces" for the creative cognitariat forming the base of the gig economy, and the recent appearance of a store called 'Vegan Doughnuts' in the last month in the formerly middle- and working class, mixeduse residential neighborhood immediately behind the hotel, mark the battle lines for what's in store for the inhabitants of this area in the years ahead.

\section{Works Cited}

Brenner, Neil. "Theses on Urbanization.” Public Culture, vol. 25, no. 1, 2013, pp. 85-114.

Burgos, Francisco and Garrido, Ginés. "Parque Río Manzanares." Ríos Urbanos, special issue of ARQ, no. 72, 2009, pp. 20-25.

Castells, Manuel. Networks of Outrage and Hope: Social Movements in the Internet Age. Polity, 2012.

“El Manzanares." Blanco y Negro, no. 902, 1908, pp. 14-15.

Fariña, José. "Madrid Río y el Manzanares.” El blog de José Fariña: urbanismo, territorio y paisaje, 19 Oct. 2010. elblogdefarina. blogspot.com/2010/10/madrid-yelmanzanares.html. Accessed 27 Apr. 2019.

Feinberg, Matthew and Susan Larson. "Cultivating the Square: Trash, Recycling and the Cultural Ecology of Post-Crisis Madrid." Ethics of Life: Contemporary Iberian Debates, edited by Katarzyna Beilin and William Viestenz, Hispanic Issues Series Vol. 42, Vanderbilt UP, 2016. pp. 113-42.

-. "The Ecological Imperative of Urban Cultural Studies." A Polemical Companion to Ethics of Life: Contemporary Iberian Debates. Vol. 7. Online open forum for discussion of essays (2016): 63-69. http:// hdl.handle.net/11299/202294 
Fernández Casadevante Kois, José Luis, Nerea Morán and Fernando Prats, eds. Ciudades en movimiento: Avances y contradicciones de las politicas municipalistas ante las transiciones ecosociales. Foro Transiciones, 2018.

Ferrer, José María. Visión romántica de Madrid en los relatos y estampas de los viajeros extranjeros del siglo XIX. Viajes Ilustrados, 1997.

Fraser, Benjamin. 'Madrid's Retiro Park as Public-Private Space and the Spatial Problems of Spatial Theory." Social \& Cultural Geography, vol. 8, no. 5, 2007, pp. 673-700.

Frost, Daniel. Cultivating Madrid: Public Space and Middle-Class Culture in the Spanish Capital, 1833-1890. Bucknell UP, 2008.

Garrido Colmenero, Ginés. "Madrid Río o el retorno de la urbe a la geografía del Manzanares." Revista PH91: proyectos, actuaciones y experiencias, no. 91, 2017, pp. 100-117.

Harvey, David. Consciousness and the Urban Experience: Studies in the History and Theory of Capitalist Urbanization. The Johns Hopkins University Press, 1985.

- Justice, Geography and the Nature of Difference. Blackwell, 1996.

-_-_. Rebel Cities. From the Right to the City to the Urban Revolution. Verso, 2012.

Heathcoate, Edwin. "Matadero Madrid, Spain.” Financial Times. 9 Apr. 2014. https://www.ft.com/content/44ad112abf3d-11e3-a4af-00144feabdc0. Accessed April 10, 2019.

Kemper, Benjamin. "16 Under-the-radar Things to Do in Madrid." Fodor's Travel. 22 Sept. 2016. www.fodors.com/world/ europe/spain/madrid/experiences/news/ photos/under-the-radar-things-to-do-inmadrid. Accessed 27 Apr. 2019.

Latour, Bruno. Facing Gaia: Eight Lectures on the New Climatic Regime. Translated by Catherine Porter. Harvard UP, 2017. López, Isidro and Emmanuel Rodríguez. "The Spanish Model." New Left Review no. 69, 2011, pp. 5-69.
"Madrid Matadero: Centro de Creación Contemporánea." Culture for Cities and Regions. nws.eurocities.eu/MediaShell/media/Madrid_Matadero\%20Madrid_06072015.pdf Accessed 20 Apr. 2019.

Ortiz de Landazuri, Roberto, Ignacio García Martínez, and Jaime Diz Sanz. "Madrid Río / Burgos \& Garrido + Porras La Casta + Rubio \& A-Sala + West 8." ArchEyes, 8 Aug. 2016, http://archeyes.com/madrid-rio/. Accessed 27 Apr. 2019

Prádanos, Luis I. Postgrowth Imaginaries: New Ecologies and Counterhegemonic Culture in Post-2008 Spain. Liverpool UP, 2018.

"Qué es Intermediæ," Interrmedia. Madrid Destino Cultura Turismo y Negocio, S.A., www. intermediae.es/en/node/3346. Accessed 3 March 2020.

Sassen, Saskia. The Global City: New York, London, Tokyo. Princeton UP, 2001.

Sequera, Jorge and Michael Janoschka. "Gentrification Dispositifs in the Historic Center of Madrid: A Reconsideration of Urban Governmentality and State-Led Urban Reconfiguration." Global Gentrifications: Uneven Development and Displacement, edited by Loretta Lees, Shin Hyun Bang and Ernesto López Morales, Policy Press, 2015. pp. 375-93.

Swyngedouw, Erik. “ $¡ L a$ naturaleza no existe! La sostenibilidad como síntoma de una planificación despolitizada." Urban. Nueva Serie, vol. 1, no. 1, 2011, pp. 41-66.

. "The Urbanization of Capital and the Production of Capitalist Natures." The Oxford Handbook of Karl Marx, edited by Matt Vidal, Tony Smith, Tomás Rotta and Paul Prew, Oxford UP, 2018, pp. 245-68.

Tkaczyk, Christopher. "The world's most popular neighborhoods, according to Airbnb." Business Insider. 16 Dec. 2019.

www.businessinsider.com/the-worlds-mostpopular-neighborhoods-according-toairbnb-2016-12. Accessed 27 Apr. 2019.

Zukin, Sharon. The Cultures of Cities. Blackwell, 1995. 